\title{
Pelatihan Terapi Ice Bath Untuk Recovery Cabang Olahraga Futsal Pada Tim Cosmo Futsal Club Jakarta
}

\author{
Robby Kurniawan ${ }^{1,}{ }^{*}$, Eko Prabowo ${ }^{1}$, Asrori Yudhaprawira ${ }^{1}$ \\ ${ }^{1}$ Fakultas IImu Pendidikan, Universitas Bhayangkara Jakarta Raya; Jl. Raya Perjuangan, \\ Marga Mulya, Bekasi Utara, Jawa Barat 17121. Telp: 021-88955882, 889955883, e-mail: \\ robby.kurniawan@dsn.ubharajaya.ac.id, e-mail: eko.prabowo@dsn.ubharajaya.ac.id, e-mail: \\ asrori.yudhaprawira@dsn.ubharajaya.ac.id \\ * Korespondensi: e-mail: robby.kurniawan@dsn.ubharajaya.ac.id
}

\begin{abstract}
Vulnerable injury and fatigue in futsal athletes at the professional level at the National level in 2019, one of the reasons is the high instability and volume during training and competition which requires every player to perform optimally in every training activity and match. This shows how important recovery programs are in an exercise program that will make the energy quickly recover and speed up the healing process when injured. One of the recovery methods that are widely used today is ice bath therapy, which is therapy by soaking in ice water with a predetermined time and temperature. This activity aims to increase the understanding of sports players both as athletes, coaches and coaching staff about one recovery model that aims to restore energy depleted during training and competition so as to make athletes recover faster and refreshed and help the healing process when an event occurs injury. In carrying out our community service activities from the Sports Coaching Education Study Program, Bhayangkara Jakarta Raya University, we hope to provide enlightenment for sports people at the Cosmo FC Team to better understand and understand the ice bath method for recovery so that the team will be better prepared to join the Futsal Professional League in Indonesia and to a higher level. In the future, Sports Coaching Education Study Program can continue to provide training and guidance on the development and progress of sports in other sports at both national and regional levels so that good cooperation in fostering sports achievements will be established and helps to produce good athletes at national and regional levels. compete at the international level in making Indonesia proud.
\end{abstract}

Keywords: Training, Therapy, Ice Bath, Recovery, Sports, Futsal

\begin{abstract}
Abstrak
Rentannya cedera dan kelelahan pada atlet futsal dilevel profesional di tingkat Nasional pada tahun 2019, salah satu penyebabnya adalah tingginya instensitas serta volume saat latihan dan pertandingan yang menuntut setiap pemain tampil maksimal dalam setiap aktivitas latihan dan pertandingan. Hal ini menunjukkan betapa pentingnya program recovery dalam suatu program latihan yang akan membuat tenaga akan cepat kembali pulih dan mempercepat proses penyembuhan saat cedera. Salah satu metode recovery yang banyak digunakan saat ini yaitu terapi ice bath yaitu terapi dengan berendam dalam air es dengan waktu dan suhu yang sudah ditentukan. Kegiatan ini bertujuan untuk meningkatkan pemahaman para pelaku olahraga baik sebagai atlit, pembina dan staff kepelatihan tentang salah satu model recovery yang bertujuan untuk memulihkan kembali tenaga yang terkuras ketika latihan dan pertandingan sehingga membuat atlit pulih lebih cepat dan segar kembali serta membantu proses penyembuhan saat terjadinya suatu cedera. Dalam pelaksanaan kegiatan pengabdian masyarakat kami dari Prodi Pendidikan Kepelatihan Olahraga Universitas Bhayangkara Jakarta Raya berharap dapat memberikan suatu pencerahan bagi pelaku olahraga di Tim Cosmo FC agar lebih memahami dan mengerti tentang metode ice bath untuk recovery sehingga membuat tim menjadi lebih siap
\end{abstract}


dalam mengikuti Liga Profesional Futsal di Indonesia maupun untuk level yang lebih tinggi. Kedepannya Prodi Pendidikan Kepelatihan Olahraga bisa terus memberikan pelatihan dan bimbingan terhadap perkembangan dan kemajuan olahraga pada cabang olahraga yang lain baik pada level nasional ataupun level daerah sehingga nantinya terjalin kerjasama yang baik dalam pembinaan olahraga prestasi serta membantu melahirkan atlet berprestasi baik dilevel nasional maupun daerah dan mampu bersaing ditingkat internasional dalam mengharumkan nama Indonesia.

Kata Kunci: Pelatihan, Terapi, Ice Bath, Recovery, Olahraga, Futsal

\section{Pendahuluan}

Olahraga merupakan, suatu kegiatan jasmani yang dilakukan dengan maksud untuk memelihara kesehatan dan memperkuat otot - otot tubuh. Kegiatan ini dalam perkembangannya dapat dilakukan sebagai kegiatan yang menghibur, menyenangkan atau juga dilakukan dengan tujuan untuk meningkatkan prestasi yang diarahkan kepada dunia industri olahraga.

Salah satu olahraga yang populer yang banyak digemari oleh masyarakat di Indonesia saat ini adalah Futsal. Futsal adalah permainan yang sangat cepat dan dinamis. Dari segi lapangan yang relatif kecil hampir tidak ada ruangan untuk membuat kesalahan (Irawan, 2009). Futsal merupakan olahraga beregu dengan permainan yang sangat cepat dan dinamis (Lhaksana, 2011). Futsal merupakan penyeragaman permainan sepakbola mini di seluruh dunia oleh FIFA, dengan mengadopsi permainan sepakbola dalam bentuk law of the game yang disesuaikan (Susworo \& Saryono, 2012). Futsal adalah aktivitas permainan invasi beregu yang dimainkan lima lawan lima orang dalam durasi waktu tertentu yang dimainkan pada lapangan, gawang, bola yang relatif lebih kecil dari permainan sepakbola yang mensyaratkan kecepatan bergerak, menyenangkan serta aman dimainkan serta tim yang menang adalah tim yang lebih banyak mencetak gol ke gawang lawannya. Futsal merupakan permainan yang dimainkan oleh 2 tim seperti permainan sepakbola yang dimainkan diruangan tertutup dengan lantai yang datar dengan pemain berjumlah 5 orang termasuk penjaga gawang. Ide permainan futsal pun sama seperti sepakbola yaitu memcetak gol sebanyak mungkin ke gawang dan mempertahankan gawang tim yang dibela dari kebobolan. Permainan futsal yang simpel, cepat dan menuntut setiap pemainnya bergerak dengan cepat serta memaksa pemainnya harus mempunya skill individu yang sangat menarik saat dilakukan membuat setiap pertandingan futsal dilevel apapun menjadi sangat menarik untuk ditonton.

Di Indonesia saat ini sudah memiliki Liga Futsal Profesional yang diikuti oleh 16 klub peserta. Salah satu peserta dari liga Futsal Profesional ini adalah Cosmo FC yang berlatih di Tifosi Sport Center, Jakarta Timur, DKI Jakarta. Dalam usaha untuk meraih prestasi maksimal di Pro Futsal League 2019, Cosmo FC sudah mempersiapkan tim untuk berlatih dengan memiliki staf pelatih yang berkualitas serta program latihan yang sudah dirancang dengan sebaik mungkin. Salah satu hal yang harus ada dalam program latihan adalah recovery atau fase pemulihan 
Recovery merupakan aktivitas yang dilakukan atlit setelah melakukan latihan ataupun pertandingan yang berguna untuk mengembalikan energi atau tenaga dari atlit untuk bersiap menghadapi latihan atau pertandingan selanjutnya. Apabila atlit mendapatkan recovery yang baik maka energi yang telah terkuras ketika latihan ataupun bertanding akan pulih lebih cepat sehingga tenaga dari atlit tadi bisa maksimal kembali. Namun padatnya jadwal latihan dan pertandingan dari Pro Futsal League 2019 menuntut tim pelatih harus kreatif dalam mempersiapkan recovey. Dengan melakukan metode pemulihan yang tepat, penurunan kinerja latihan fisik dan terjadinya berbagai cedera olahraga dapat dicegah.

Cedera olahraga secara umum dibedakan menjadi cedera traumatis dan cedera berkelanjutan (overuse injuries). Cedera traumatis terjadi akibat benturan sedangkan overuse injury terjadi akibat beban kerja fisiologis yang berlebihan. Bentuk cedera dapat berupa memar, strain, sprain sampai dengan fraktur tulang. Respon tubuh terhadap kerusakan jaringan ini berupa reaksi peradangan (inflamasi) yang dipicu oleh mediator inflamasi yang dihasilkan oleh sel yang rusak maupun mati. Karakteristik peradangan berupa nyeri (dolor), pembengkakan(tumor), kemerahan (rubor), peningkatan suhu (kalor) serta penurunan fungsi (function leissa). Pada keadaan ini terjadi kerusakan pembuluh darah yang menimbulkan perdarahan pada jaringan. Pada stadium lanjut terjadi proses penjendalan yang difasilitasi oleh trombosit, faktor penjendalan darah dan fibroblast yang membentuk jaringan parut. Apabila terjadi kegagalan 2 maupun keterlambatan proses penyembuhan, respon tubuh memasuki fase kronis. Pada fase ini sudah tidak dijumpai tanda peradangan yang dominan kecuali penurunan fungsi dan rasa nyeri. Tahap peradangan merupakan bagian dari proses penyembuhan, walaupun demikian respon peradangan yang berlebihan dapat memperlambat proses penyembuhan akibat dari limbah metabolisme yang berlebihan sehingga pada fase akut dilakukan usaha untuk menekan respon peradangan.

Dewasa ini terapi dingin banyak digunakan pada fase akut cedera olahraga. Berbagai bentuk terapi seperti masase es, ice pack, cold bath, vapocoolant spray dan cyrokinetics digunakan untuk mengatasi peradangan dan mengurangi waktu yang diperlukan untuk pemulihan cedera lewat berbagai mekanisme fisiologis (Hurme, 1993). Perubahan suhu jaringan bervariasi tergantung bentuk terapi, waktu pemaparan, suhu awal dan lokasi anatomis (Bleakley, 2004). Efek fisiologis terapi dingin disebabkan oleh penurunan suhu jaringan yang mencetuskan perubahan hemodinamis lokal dan sistemik serta adanya respon neuromuscular. Terapi dingin secara klinis dapat meningkatkan ambang nyeri, mencegah pembengkakan dan menurunkan performa motorik lokal (Hocutt, 1982). Walaupun demikian aplikasi dingin yang berkepanjangan harus dihindari untuk mencegah terjadinya efek samping antara lain iritasi, hipothermia dan frost bite (Swenson, 1996). Penggunaan terapi dingin harus dilakukan pada indikasi yang tepat serta dihindari pada keadaan yang merupakan kontra indikasi.

Salah satu metode pemulihan yang banyak digunakan saat ini adalah cold water immersion atau yang lebih dikenal sebagai ice bath atau berendam di dalam kolam es. Pada dasarnya, metode pemulihan dengan kolam es akan membantu mengatasi rasa sakit setelah 
melakukan latihan fisik yang berat. Mekanisme kerjanya berhubungan dengan respon tubuh terhadap suhu dingin yang dikatakan dapat menurunkan reaksi inflamasi tubuh yang terjadi akibat latihan fisik. Suhu dingin akan merangsang sistem saraf yang berada di dekat permukaan kulit untuk menurunkan aliran darah ke jaringan tersebut sehingga pembengkakan dan inflamasi yang terjadi akan berkurang. Sensasi dingin tersebut juga dapat menurunkan nilai ambang nyeri sehingga sering digunakan untuk terapi cedera akibat trauma latihan fisik.

Menurut (Konrath, 1996:630) beberapa kondisi yang dapat ditangani dengan cold therapy antara lain : Cedera (sprain, strain dan kontusi), sakit kepala (migrain, tension headache dan cluster headache), gangguan temporomandibular (TMJ disorder), testicular dan scrotal pain., nyeri post operasi, fase akut arthritis (peradangan pada sendi), tendinitis dan bursitis, carpal tunnel syndrome, nyeri lutut, nyeri sendi, nyeri perut.

Di Indonesia sendiri, penggunaan terapi ice bath mulai terkenal pada tahun 2013. Penyebabnya adalah keberhasilan Tim Nasional Sepakbola Indonesia U.19 yang di pimpin oleh pelatih kepala Indra Syafri saat itu untuk pertama kalinya berhasil membawa Indonesia menjadi juara piala AFF U.19 tahun 2013. Dan masih di tahun yang sama tim ini pun berhasil lolos untuk mengikuti turnamen piala Asia U.19 setelah di babak kualifikasi berhasil menumbangkan tim juara bertahan yaitu Korea Selatan. Hal ini membuat banyak pihak dan media yang ingin mengetahui apa saja aktivitas yang dilakukan sehingga pencapaian tim ini saat itu dinyatakan cukup berhasil. Dan salah satu aktivitas dari Tim Nasional Sepak Bola U.19 saat itu adalah terapi ice bath yang rutin dilakukan saat aktivitas recovery yang terbukti membuat kondisi atlit cukup terjaga. Dan semenjak saat itu beberapa tim profesional sepakbola dan beberapa cabang lainnya juga mulai menggunakan metode terapi ice bath untuk aktivitas recovery setelah berlatih maupun bertanding.

Tujuan dari kegiatan ini adalah memberi pelatihan tentang metode recovery ice bath yang tepat. Serta manfaat pada kegiatan ini yang pertama yaitu membantu tim mempersiapkan atlit dalam menghadapi padatnya jadwal pertandingan dan latihan serta mencegah terjadinya cidera serta mempercepat proses pemulihan pada atlit futsal. Sasaran pada kegiatan ini akan di sampaikan kepada tim Futsal Cosmo FC mulai dari pemain dan staf pelatih. Kegiatan pengabdian masyarakat ini di adakan pada tanggal 24 November 2018 dan berlokasi di Tifosi Sport Center, Jakarta Timur, DKI Jakarta.

\section{Metode Pelaksanaan}

\section{A. Metode Pengumpulan Data}

Digunakan untuk mengumpulkan data-data mengenai kegiatan yang akan dilakukan yaitu di Tim Futsal Cosmo FC, Jakarta Timur, DKI Jakarta. Dimana pengabdian kepada masyarakat ini akan diselenggarakan di Tifosi Sport Center, Jakarta Timur, DKI Jakarta. 


\section{B. Menentukan Tema Pengabdian yang akan diberikan}

Berdasarkan hasil diskusi dengan pimpinan dan tim pelatih Tim Cosmo FC, maka dipilih materi tentang recovery dalam olahraga, dimana metode recovery yang digunakan adalah metode ice bath.

\section{Mencari Studi Pustaka}

Studi pustaka adalah teknik pengumpulan data referensi dari berbagai jenis sumber keilmuan yang menunjang permasalahan beserta solusinya. Dalam kegiatan pengabdian kepada masyarakat ini, Pelatihan tentang Pelatihan Terapi Ice Bath Untuk Recovery Cabang Olahraga Futsal Pada Tim Cosmo Futsal Club

\section{Membuat Materi Pelatihan}

Berdasarkan studi pustaka yang telah dilakukan, maka dibuatlah materi Pelatihan yang dibuatkan ke dalam modul berupa presentasi menggunakan powerpoin dan praktek mengenai pelatihan terapi Ice Bath untuk Recovery. .

\section{E. Menyajikan Pelatihan}

Pelatihan ini dilaksanakan dengan metode ceramah, diskusi, simulasi dan praktek. Pelaksanaan ini dilaksanakan di Tifosi Sport Center, Jakarta Timur, DKI Jakarta. Peserta pelatihan adalah Seluruh anggota tim mulai dari semua pemain, staf pelatih dan manajer dari tim Cosmo FC, dengan waktu pelaksanaan 1 hari.

Dalam kegiatan ini terdiri dari beberapa sesi, yakni:

Sesi I (Pembukaan)

Pembukaan dan perkenalan pemateri

Sesi II (penyampai materi)

Penyampaian materi dari para pemateri

Sesi III (tanya jawab)

Sesi IV (Praktek terapi Ice bath yang diikiti seluruh tim Cosmo FC)

Sesi V ( penutup)

Pada pelaksanaan kegiatan pelatihan ini akan disediakan beberapa hal:

Susunan Acara

Bahan materi penyuluhan

TOR (Term Of Referrence) Pemateri

\section{Hasil dan Pembahasan}

Pelatihan Terapi Ice Bath Untuk Recovery

- Recovery : Pemulihan

Mengembalikan kondisi / keadaan dalam situasi bersiap kembali

- Recovery Dalam Olahraga

- Recovery adalah waktu yang digunakan untuk pemulihan tenaga kembali antara satu elemen beban pelatihan berikutnya. 
Jenis Recovery Dalam Olahraga

Recovery aktiv

Istirahat Total

Istirahat dengan Nutrisi (Makanan, Minuman)

Massage

Cold Water Immersion (Terapi air dingin / ice bath)

Recovery BOOTS

Pelaksanaan Terapi Ice Bath

Alat Yang Dibutuhkan

1. Area penampungan air

2. Es Balok

3. Air

4. Alat Pengukur Suhu

5. Stopwatch

\section{Aturan Pelaksanaan Terapi Ice Bath}

20 Menit, Dibagi dalam 3 kali pelaksanaan, dengan 1 meint keluar dari kolam es selama 1 menit untuk berendam di air normal dan kembali ke air es (David Setiawan, Sport Terapis Tim Arema $\mathrm{FC)}$

10 menit di air es, dan 1 menit berendam di air normal (Budi Kurnia, Pelatih Fisik Persis Solo) 12 menit di air es, dibagi dalam 2 kali pelaksanaan, 6 menit air es, 1 menit air normal, 6 menit air es ( Matias Ibo, Praktisi Kesehatan Olahraga, Fisioterapis TimNas Sepakbola Indonesia (2010), Semen Padang FC Fc ( 2014-2016), PS TNI ( 2017).

Beberapa kondisi yang dapat ditangani dengan cold therapy antara lain:

- Cedera (sprain, strain dan kontusi)

- Sakit kepala (migrain, tension headache dan cluster headache).

- Gangguan temporomandibular (TMJ disorder).

- Testicular dan scrotal pain.

- Nyeri post operasi..

- Fase akut arthritis (peradangan pada sendi).

- Tendinitis dan bursitis.

- Carpal tunnel syndrome.

- Nyeri lutut.

- Nyeri sendi.

- Nyeri perut.

Efek Fisiologis dan Terapetis Terapi Dingin

Vasokontriksi

Piloereksi 
Menggigil

Vasokontriksi lokal

Desensitisasi akhiran saraf

Penururunan refill kapiler

Penurunan metabolism sel

Relaksasi otot

Menghambat pertumbuhan bakteri

Mencegah pembengkakan

Mengurangi nyeri

Mengurangi perdarahan

Dokumentasi Saat Kegiatan terlihat pada gambar 1.
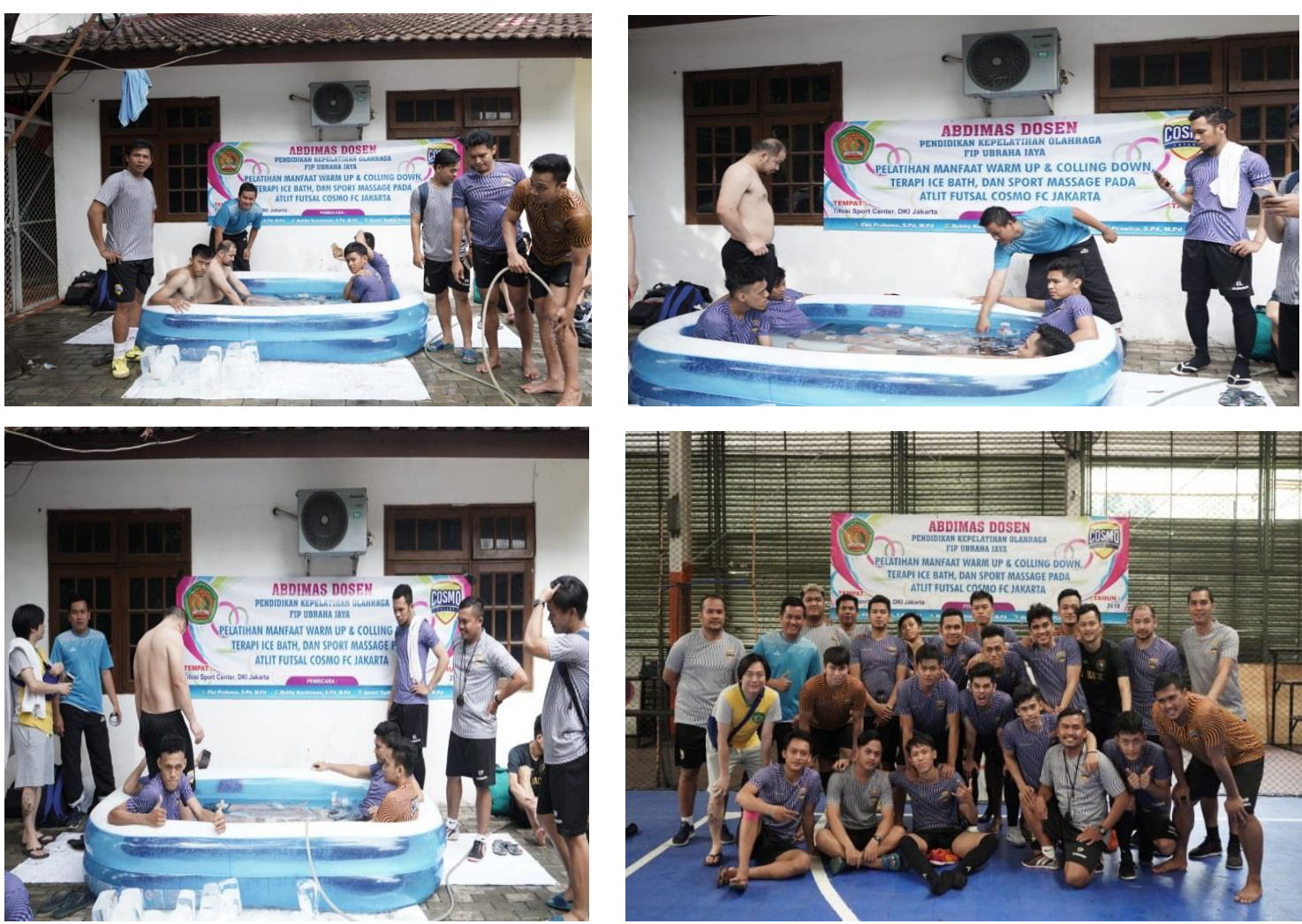

Sumber: Hasil Pelaksanaan (2020)

Gambar 1. Pelatihan Terapi Ice Bath

\section{Kesimpulan}

Simpulannya sebagai berikut: Olahraga merupakan bagian yang tidak terpisahkan dari upaya penigkatan kualitas kesehatan dan kebugaran. Namun olahraga harus dilaksanakan sesuai dengan kaidah yang tepat agar tujuannya dapat tercapai dengan maksimal .Recovery merupakan bagian yang sangat penting dalam olahraga, terutama olahraga prestasi. Karena recovery yang tepat akan membantu proses pemulihan kondisi tubuh yang terkuras ketika berolahraga serta membantu mempercepat penyembuhan ketika mengalam cedera. Rekomendasinya yaitu: 1). Diharapkan untuk pemain, pelatih, serta pembina organisasi dan 
klub olahraga lebih memahami tentang pentingnya recovery dalam berolahraga untuk mempercepat proses pemulihan energi dan penyembuhan cedera. 2). Diharapkan dalam Tim Cosmo Futsal Club, baik sebagai pemain ataupun official dapat menerapkan dan mengembangkan pengetahuan yang diperoleh dalam pelatihan, untuk kegiatan olahraga prestasi, pendidikan maupun olahraga rekreasi.

\section{Ucapan Terima Kasih}

Kami mengucapkan banyak terima kasih kepada semua pihak yang telah terlibat dalam kegiatan pengabdian kepada masyarakat ini baik langsung maupun tidak. Terutama kepada peserta Tim Cosmo Futsal Club Jakarta.

\section{Daftar Pustaka}

Susworo, A. D.M. (2014). International Seminar of Sport Culture and Achievement. Diakses dari http://staff.uny.ac.id/sites/default/files/penelitian/agus-susworo-dwi-marhaendrospdmpd/validity-and-reliability-futsal-skill-test.pdf. Pada tanggal 21 Juli 2018

Irawan, A. (2009). Teknik Dasar Modern Futsal. Jakarta : PT. Pena Pundi Aksara

Bleakley, C., S. McDonough \& D. MacAuley (2004). "The use of ice in the treatment of acute soft-tissue injury." The American journal of sports medicine 32(1): 251.

Hocutt, J. E. (1982). "Cryotherapy in ankle sprains." The American journal of sports medicine 10(5): 316.

Hurme, T., J. Rantanen \& H. Kaliomo (1993). "Effects of early cryotherapy in experimental skeletal muscle injury." Scandinavian journal of medicine \& science in sports 3(1):46.

Justinus Lhaksana. (2011). Taktik \& Strategi Futsal Modern. Jakarta: Penebar Swadaya Group

Konrath, G. A., T. Lock, H. T. Goitz \&J. Scheidler (1996). "The use of cold therapy after anterior cruciate ligament reconstruction: a prospective, randomized study and literature review." The American journal of sports medicine 24(5): 629

Swenson, C., L. Swärd \& J. Karlsson (1996). "Cryotherapy in sports medicine. Scandinavian journal of medicine \& science in sports 6(4): 193. 